Running Head: SOCIAL NETWORKS AND REFORM

\title{
Relationships in Reform: The Role of Teachers' Social Networks
}

\author{
Alan J. Daly \\ University of California, San Diego \\ Nienke Moolenaar \\ Twente University \\ Jose M. Bolivar \\ University of California, San Diego \\ Peggy Burke \\ Transformative Inquiry Design for Effective Schools
}

Contact Information:

Alan J. Daly

University of California, San Diego

ajdaly@ucsd.edu

805.252.7819 


\title{
Relationships in Reform: The Role of 'Teachers' Social Networks
}

\begin{abstract}
Purpose-Scholars have focused their attention on systemic reform as a way to support instructional coherence. These efforts are often layered onto existing social relationships between school staff that are rarely taken into account when enacting reform. Social network theory posits that the structure of social relationships may influence the direction, speed, and depth of organizational change and therefore may provide valuable insights in the social forces that may support or constrain reform efforts.

Design-This mixed-methods exploratory case study examined five schools within one underperforming school district as it enacted a system-wide reform. Quantitative survey data was collected to assess social networks and teacher work perception of five schools enacting the reform. Qualitative data was gathered through individual interviews from educators within representative grade levels as a way to better understand the diffusion and implementation of the reform.

Findings-Despite being enacted as a system wide reform effort, results suggests significant variance within and between schools in terms of reform-related social networks. These networks were significantly related to the uptake, depth, and spread of the change. Densely connected grade levels were also associated with more interactions focused on teaching and learning and an increased sense of grade level efficacy.

Research/Practice Implications-Our findings underline the importance of attending to relational linkages as a complementary strategy to the technical emphasis of reform efforts, as social networks were found to significantly facilitate or constrain reform efforts. We offer implications and recommendations for leadership, policy and practice that may support the design and implementation of reforms, that may ultimately increase student performance.

Originality/value-This study makes a unique contribution to the reform literature by drawing on social network theory as a way to understand efforts at reform. Our work suggests that the informal social linkages upon which reform is layered may support or constrain the depth of reform.
\end{abstract}

Keywords: Reform, Social Networks, Leadership, Collaboration, Change

Paper Type: Research Paper 


\section{Relationships in Reform: The Role of 'Teachers' Social Networks}

\section{Introduction}

Efforts at improving public educational systems in support of better student achievement are commonplace across the globe. Many countries have experienced or are experiencing prime ministers, premiers, or presidents that define themselves as the 'education' leader and as such enact a series of changes targeted at improving their nation's schools. For many of these schools there is almost a revolving door of reforms (Henig and Stone, 2008). This 'reform churn', while intended to improve performance, often constrains efforts at organizational improvements as change-weary schools often engage reforms with a lack of depth and breath (Coburn, 2003; Datnow, Lasky, Stringfield and Teddlie, 2006; Hubbard, Mehan and Stein, 2006). Reform efforts are typically implemented using a variety of formal structures, processes, and accountability levers to improve performance. However, while these more formal, technical approaches at improving education are important and have been well documented, what has been less thoroughly explored in the change equation, are the relational linkages between actors through which reform flows (Coburn and Russell, 2008; Penuel, Riel, Krause and Frank, 2009).

While educational scholars throughout the world acknowledge the importance of interpersonal relationships and social interaction for continuous school improvement and organizational change (Carmichael, Fox, McCormick, Procter and Honour, 2006; Hopkins and Reynolds, 2001; James, Dunning, Connolly, and Elliot, 2007; Moolenaar, Sleegers, Karsten, and Zijlstra, 2009), knowledge about the social structures in which school reforms take place is scarce. Findings from organizational literature indicate that organizational improvement is closely linked to the ties within and across systems (McGrath and Krackhardt, 2003; Tenkasi and Chesmore, 2003). In education, this has led to the development of professional learning communities and emphasis on collaborative structures targeted at the grade level (McLaughlin and Talbert, 1993; Newmann and Wehlage, 1995; Wood, 2007; Stoll and Louis, 2007). Most often, these types of communities are developed to increase communication and collaboration among teachers within and across grade levels (Stoll and Louis, 2007). Recent research has suggested that informal social structures, in particular, provide opportunities for information transfer and development of new knowledge between individuals and levels in organizations (Ahuja, 2000; Tsai and Ghoshal, 1998). To date, there is little empirical understanding of how the underlying social networks, in which district-wide change efforts take place, support or constrain reform efforts (Coburn and Russell, 2008). A more in-depth investigation of the social networks within schools may uncover important characteristics of these social structures that facilitate or impede efforts at system-wide reform.

To better understand how underlying patterns of social interactions within schools may affect reform efforts over time, we draw upon social network theory and methods. Social network analysis is a systemic approach used to quantify and visualize the ties and overall structures of formal and informal networks. Given the increasing number of underperforming educational systems across the globe there is an urgency to better understand the relational complexities of these organizations (Lima, 2009). Examining the structure of social networks may assist educators in better managing and leveraging patterns of interactions in support of meeting specific targeted academic goals (Ahuja, 2000; Tsai and Ghoshal, 1998).

In this study we examine the social networks of teachers in five schools as they engage a district- 
wide effort at reform. A 'district' in this context refers to a group of schools within a specific geographic region that are supported by a singular central office. Our exploratory case study takes place in the Esperanza ${ }^{1}$ School District, an urban fringe district that is in the third year of progressive sanction for underperformance. In an effort to improve student achievement, the district has undertaken a targeted system-wide approach to reform focused on reading comprehension targeted at the grade level. In this article, we explore three social networks among teachers that represent social interactions related to these reform efforts: the social networks of lesson planning, reading comprehension, and effort recognition. Our aim is to determine how these networks may facilitate or constrain the reform initiative in this underperforming district. Our study is guided by the following research questions:

1. To what extent do formal and informal social network structures within grade levels support or constrain the access and exchange of collaborative lesson planning, knowledge of reading comprehension, and reform-related effort recognition around the district-wide change effort?

2. How do teachers in different formal and informal positions in the network both perceive the relational linkages through which the reform is diffused and enacted?

3. To what extent are social network structures related to teachers' perceptions of collective action, efficacy and satisfaction with regard to the reform?

We first provide our theoretical framework in which we briefly outline the importance of the district in reform efforts and how those efforts may be supported by teacher action and collaboration. We then provide a review of social network theory and analysis as a conceptual lens to understand the impact of social linkages on reform. We propose that these literatures provide a useful frame to deepen our understanding as to how social networks may facilitate or inhibit efforts at reform.

\section{Theoretical Framework}

\section{District Reform and Collaboration}

To better understand the context in which contemporary schools operate, a number of scholars have shifted their focus from the school site as the unit of reform to the relationship between central offices and sites (Elmore and Burney, 1997; Hightower, Knapp, Marsh and McLaughlin, 2002; Honig, 2006; McLaughlin and Talbert, 2003; Rorrer, Skrla and Scheurich, 2008; Togneri and Anderson, 2003). This line of inquiry acknowledges that schools are embedded within a larger context and that this context may have a direct impact on the success of improvement efforts (Copland and Knapp, 2006; Massell and Goertz, 1999; Rorrer et al., 2008; Spillane, 1996). One approach to reforming districts is a system-wide approach to improvement (Honig and Hatch, 2004), in which district administrators re-orient organizational structures and processes to align with reform goals (Rorrer, et al., 2008). This reorientation, Datnow and Castellano (2003) argue create "supportive conditions at the district level that are important to successful implementation and sustainability of whole school reform" (p. 203).

Successful reform efforts, therefore, may require a shift in the way that change strategies are conceptualized and enacted within a school district. This shift entails a move from a singular focus on individualized segments of the organization to engaging the entire system in a network of connections. For example, a successful networked approach has been demonstrated in the United

\footnotetext{
${ }^{1}$ All names are pseudonyms
} 
Kingdom through the National College of School Leadership's (NCSL) Network Learning Group of 104 schools (Earl and Katz, 2007; Earl, Katz, Elgie, Ben-Jaafar and Foster, 2006). This network yielded positive outcomes in a variety of areas including developing leadership, strengthening communities, and positively influencing student achievement (Earl et al., 2006). Facilitative conditions for these successful networks included frequent and pervasive communication, shared understanding and purpose, joint challenging work, and relationships built on trust that enabled the transfer of tacit and explicit knowledge (Earl and Katz, 2007). Although the NCSL project represents a much broader network of schools than may exist in a single school district, implications from this work potentially hold importance as a way to create and understand networks within school districts. Above all, the balance of this work suggests the need for a more interconnected systems approach to organizational change (Fullan, 2005; Hargreaves and Fink, 2006; McLaughlin and Talbert, 2003), requiring that district and site leaders, “....think systemically about schools and their development and see educational organizations in terms of their interdependent parts" (Smylie, Wenzel and Fendt, 2003; p. 155).

Studies of successful districts that applied more systemic approaches in developing collaboration across teams suggest a range of specific strategies that educators can engage in building stronger intra-organizational ties (Chrispeels, 2004; Honig, 2004; Togneri and Anderson, 2003). These strategies include; creating structures for increased collaboration and knowledge exchange within schools (McLaughlin and Talbert, 2003), enhancing communication channels and support focusing on teaching and learning (Agullard and Goughnour, 2006), distributing leadership (Leithwood, et al., 2007; Spillane, 2006), providing opportunities for input on decision-making (Brazer and Keller, 2008), and building a collective sense of efficacy (Goddard, Hoy and Hoy, 2004).

The significance of collaborative structures and social networks for successful school improvement and continuous teacher development is underlined by studies on educational reform and school change across the globe, such as southeast Asia (Hallinger, 1998), Australia (Hollingsworth, 2004), the Netherlands (Moolenaar, Sleegers and Zijlstra, 2009; Moolenaar, Daly, and Sleegers, 2009; Veugelers and Zijlstra, 2002), Portugal (Lima, 2007, 2009), Uganda (Hite et al., 2006), the United Kingdom (Durrant and Holden, 2006; Earl and Katz, 2007; Hargreaves, 2001, 2003; Hopkins and Reynolds, 2001), and the United States (Daly and Finnigan, 2009). Whether in the form of communities of practice (Wenger, 1998), learning organizations (Senge, 2006), professional learning communities (McLaughin and Talbert, 1993; Newmann and Wehlage, 1995; Stoll and Louis, 2007), or distributed leadership (Spillane, 2006), the social context, and in particular increased social interaction among all of the school's stakeholders, is believed to be at the heart of system reform and school improvement.

The work of reform through a social context is captured well by Hubbard and colleagues (2006), who in their book on district reform define an organization as existing "in the interrelationships between activities of individuals" (p. 263). It is the interaction between and among individuals that comprises the culture and structure of an organization. The assumption that undergirds this definition is that changes in educational systems are often socially constructed (Hubbard, et al., 2006). Therefore, attempts to modify formal structures in support of reform often require changes in existing social relationships (Borgatti and Foster, 2003; Stevenson, Bartunek and Borgatti, 2003). It is the organizational interdependence of action (Giddens, 1979), reflecting a network of ties, that may ultimately moderate, influence, and even determine the direction, speed, and depth of a planned change (Krackhardt, 2001; Mohrman, Tenkasi and Mohrman, 2003). According to Mohrman et al. (2003), because change processes emerge and are maintained through interpersonal relationships, 
"...lasting change does not result from plans, blueprints, and events. Rather change occurs through the interaction of participants (p. 321)." This research suggests that the careful exploration and analysis of social networks in an organization may broaden the understanding of the factors that support or constrain organization wide reform (Tenkasi and Chesmore, 2003).

Teachers that are able to successfully engage in collaborative work have been defined as "group of people across a school who are engaged in common work; share to a certain degree a set of values, norms, and orientations towards teaching students, and schooling; and operate collaboratively with structures that foster interdependence" (Achinstein 2002, p. 421-422). Teacher teams' ability to make decisions and focus action related to instruction has been associated with access to expertise and instructional knowledge (Andrews and Lewis, 2007; Frank, Zhao and Borman, 2004; Johnston, Knight and Miller, 2007; Louis and Marks, 1998; Love, 2008; McLaughlin and Talbert, 2006; Smylie, 1996). Teachers working in collaboration tend to have a wider skill variety, be more informed about their colleague's work and student performance, report increased instructional efficacy, and are more likely to express higher levels of satisfaction (Chrispeels, Andrews and Gonzalez, 2007; Little, 2003; Moore-Johnson, 2004; Stoll and Louis, 2007; Wenger, 1998). Although there have only been limited studies on the direct connection between patterns of reform-related social interaction in teacher networks and student outcomes, recent work suggests that teacher collaboration around curriculum and instruction is related to student achievement (Goddard, Goddard and Tschannen-Moran, 2007).

Studies suggest that teachers who collaborate are better able to access and make use of the individual and collective resources embedded in their professional network (Rigano and Ritchie, 2003). These 'professional learning communities' have a rich international presence as has been documented by Stoll and Louis (2007), who, in a variety of global contexts, have noted the importance and potential of teachers working together. As teachers design and plan together, best practices are shared and developed through their discussion (Chrispeels, et al., 2007; Little, 2003; Wenger, 1998). It is this partnership of action and learning that may enable reforms to be better taken up at the school level (Hubbard et al., 2006). However, despite the growing empirical base around teacher work in professional communities, there still exists a significant gap in our knowledge as to the quality of collaborations and how these social interactions may impact the depth of district reform (Coburn and Russell, 2008; Little, 2003). Therefore, given the identified gaps and importance of better understanding teacher collective action, efficacy, and satisfaction in reform (Chrispeels, Andrews and Gonzalez, 2007; Goddard, Hoy and Hoy, 2004; Little, 2003; Moore-Johnson, 2004; Stoll and Louis, 2007), we will include these important variables for examination as well as how these constructs may be associated with reform-related networks. We now introduce social network theory as a lens to explore how patterns of social interaction among teachers may support or constrain district-wide efforts at reform.

\section{Social Network Theory}

One of the basic conceptual foundations in understanding social network theory is the concept of social capital. A number of theorists have written on social capital; each foregrounding a different aspect of the concept and offering nuanced understanding of the idea (see, for example, Bourdieu, 1986; Burt, 1992; Coleman, 1988; Lin, 2001; Putnam, 1993). Lin (2001) notes that the common denominator between all major theorists includes the understanding that social capital consists of: "The resources embedded in social relations and social structure which can be mobilized when an actor wishes to increase the likelihood of success in purposive action" (p. 24). Social capital is therefore composed of a system's social relations through whom the resources of other individuals 
can be accessed, borrowed, or leveraged. This differentiates social capital from human capital, which refers to training, development, or certifications of individuals, or physical capital that is contained in infrastructure and equipment (Bourdieu, 1986; Coleman, 1988; Dika and Singh, 2002; Lin, 2001).

Social capital is concerned with the resources that exist in social relationships (sometimes referred to as 'ties') between individuals as opposed to the resources of a specific individual. This implies that actors must be aware of the assets in their network and take action through social ties to access these resources (Portes and Sensenbrenner, 1993). It is the quality of those ties between individuals in a social system that creates a structure that ultimately determines opportunities for social capital transactions and access to resources (Burt, 1992; Coleman, 1988, 1990; Granovetter, 1982; Lin, 2001; Putnam, 1993). Strong social ties support the transfer of tacit, non-routine, or complex knowledge (Hansen, 1999; Reagans and McEvily, 2003), joint problem solving, and the development of coordinated solutions (Uzzi, 1997). Strong ties have also been associated with low-conflict organizations (Nelson, 1989). Less dense networks tend to be better suited for the transfer of simple, routine information (Hansen, 1999) and can provide for brokering opportunities between actors (Burt, 1992; Granovetter, 1973). Taken together, both strong and weak ties are necessary within a social structure as they facilitate access to different kinds of information (Haythornthwaite, 2001; Tenkasi and Chesmore, 2003).

Networks can be identified by the content that is transacted through the social ties (Scott, 2000; Wasserman and Faust, 1998). For example, communication networks may encompass information exchange, knowledge transfer, and advice. The content that flows through relationships defines the purpose of the network and how well the resources flow between actors (Wasserman and Faust, 1998). For example, the social structure of a work-related knowledge network may differ significantly from the structure of a more normative social network, such as trust. In both examples resources flow through ties (the first being knowledge, the second trust), but the overall structure of the network may look quite different.

Network structures may facilitate the transfer of resources if the necessary relationships are in place and are accessible, but they may also constrain resource exchanges if the network does not hold sufficient connected ties to move the resource (Daly and Finnigan, 2009; Hite, Williams and Baugh, 2005). In many cases, the underlying social structure determines the type, access, and flow of resources to actors in the network leading some scholars to suggest that the old adage 'It is not what you know, but who you know', is more accurately, 'Who you know defines what you know' (Cross, Baker and Parker, 2003). Therefore, understanding network structures may be useful for educational organizations enacting reform efforts as these underlying networks may be leveraged to better create, use, and diffuse knowledge and evidence (Cross, et al., 2003). These resources may be of particular use as schools and districts attempt to diffuse reform strategies as a way to meet demands in high-stakes educational contexts.

The balance of scholarship in this section points to the value of exploring the network interactions in schools within a school district engaged in a focused reform. Dense interconnected networks at all levels of an organization may facilitate the uptake of complex knowledge thus increasing the potential for organizational change. International interest in social networks in the field of education has to date resulted in analyses of principal networks (Friedkin and Slater, 1994); school and teacher networks (Bakkenes, De Brabander and Imants 1999; Coburn and Russell, 2008; Granovetter, 1986; Penuel, Frank and Krause, 2007; Penuel, et al., 2009); teacher professional 
development networks (Lima, 2007); departmental structures (Lima, 2003, 2004; Spillane, 2006); school-parent networks (Horvat, et al., 2003); and between school networks (Mullen and Kochan, 2000; Earl and Katz, 2007). Although it has been recently suggested (Coburn and Russell, 2008; Penuel, et al., 2009), there are few studies that examine the social networks of teachers in reform and even fewer that explore these networks in underperforming schools. This study builds on recent scholarship emphasizing the importance of understanding relational linkages in support of organizational outcomes (Balkundi and Kilduff, 2005; Daly and Finnigan, 2009; Kilduff and Krackhardt, 2008); and makes a unique contribution to the literature by describing how district reform unfolds through teacher networks and related grade-level work measures in five schools as they take up a district-wide reform effort.

\section{Methodology}

An exploratory case study design was used to examine three social networks that described the reform-related social interactions in the sample schools: the social networks of collaborative lesson planning, knowledge around reading comprehension and effort recognition. In addition, we collected a series of grade level teacher work measures related to collective action, efficacy, and satisfaction. A case study approach is most appropriate when the phenomenon of interest has a level of complexity that requires multiple data sources and methods to gain an in-depth understanding (Yin, 2003). We used social network analysis (SNA) (Scott, 2000; Wasserman and Faust, 1998), grade level work measures (Bryk, Camburn, and Louis, 1999, Goddard, Hoy and Woolfolk Hoy, 2000), and semi-structured interviews (Patton, 1990) to better understand how these social networks support or constrain the uptake of the reform initiated by the Esperanza School District (ESD). We selected this particular district, as it has been enacting a district-wide reform effort around reading comprehension for the past two years in response to its underperformance.

Context. The Esperanza School District (ESD) is an urban fringe district near San Diego, California USA. Being in the third year of sanction from the federal government for underperformance, Esperanza typifies systems that have enacted multiple reform initiatives in order to meet accountability mandates and increase student performance. The district currently serves 18,745 students in kindergarten through eighth grade in 24 schools, representing the student diversity found in many schools across California (the most populous state in the US) and in urban settings across the globe. Esperanza's underperformance with low achievement scores in English Language Arts (ELA) prompted the district-wide reform focus on reading comprehension. In an effort to increase achievement in ELA across all schools for the past year and a half, ESD has been implementing a district-wide reform centered on reading comprehension aimed at the grade level. The reform includes; a district-wide literacy curriculum, instructional strategies for reading comprehension, targeted professional development, and a commitment for a multi-year sustained effort. The intent of the reform is to provide a consistent approach across all schools to ensure access to high quality literacy instruction and improve district performance.

We selected five ESD elementary schools representing grades kindergarten (age of students 5 years) through fifth grade (age of students 10 years) as sample schools. The schools were selected as they are reflective of the range of schools in the district with regard to socio-economic background and academic performance levels. In addition, the five sample schools were involved in a University partnership that provided supplementary professional development and a team-based collaborative approach around the reform focus. Although the schools are representative in regard to district-wide 
demographics, their participation in this University partnership does make them different than other district schools. However, we purposely selected these schools, as they presumably should have the 'best' opportunity to consistently enact the district change given the additional reform support. Therefore, this sample represents a 'best case' laboratory to test out the degree to which social networks support or constrain reform efforts. Table 1 provides the demographic data for the district and sample schools including the Academic Performance Index (API) score. API is a California state measure of a school's academic performance on a scale of $200-1000$ with 800 as a target of minimum desired performance.

\section{Insert Table 1 About Here}

Aside from school size, with the sample schools being larger on average than the other schools in the district, the sample reflects overall district averages. Within the sample, the schools and grade level teams were also comparable with respect to school and team size. Overall, the network and work measures instruments, designed to collect the quantitative data for our study, had a very strong average response rate of $89 \%$, with a range from 85\% to 93\%. Final survey results represented 196 teachers and support staff (principals and coaches) in thirty grade levels across five schools. Table 2 provides the overall school staff demographics that were relatively consistent across schools.

Insert Table 2 About Here

\section{Data collection and analysis: social networks and teacher measures}

Social network data collection. In order to assess the social networks in Esperanza we developed an online survey that comprised multiple distinct networks questions. We asked site administrators, teachers, and support staff at each of the five schools to indicate the frequency of interaction with other school members. Items were generated from previous social network research (Daly and Finnigan, 2009; Cross and Parker, 2004) and accompanied by original items. We selected three types of network questions for analysis that were related to the reform effort: lesson planning collaboration, reform knowledge, and recognition of reform efforts. These network relations were selected as they have been associated with higher organizational performance in the literature outside of education (Krackhardt, 2001; Mohrman, et al., 2003). For the lesson planning collaboration network we asked every school member to respond to the survey prompt, "Please select your frequency of interaction around reading lesson planning between you and the following school members...?" The reform knowledge network was generated by the prompt, "Please select the frequency of interaction with school members with whom you share knowledge around the reading comprehension reform...?" And finally the effort recognition network was measured through the following prompt "Please select the frequency of interaction around who recognizes you for reform related efforts...?" Respondents could indicate the frequency of interaction in the relationship on a 5-point scale ranging from one (no interaction) to five (1-2 times a week). Participants within each school received a roster with their school members in rows and the frequency of interactions for each relationship in columns. This bounded method is a preferable social network strategy that provides a more complete picture of the network and thus supports valid results (Scott, 2000).

Social network data analysis. While the data collection process rendered social networks at various frequencies of interaction, we chose to focus on the most frequent interaction patterns within each of the reform networks. These interactions typically represent stable structural patterns (Krackhardt, 
2001) and respondents are more accurate at identifying ongoing patterns than determining occasional interactions (Carley and Krackhardt, 1999). In order to be considered a frequent tie individuals would have had to interact once every two weeks to a couple of times a week (4 and 5 on the rating scale). We calculated a series of network measures using the UCINET software (Borgatti, Everett and Freeman, 2002) on each of these frequent relationships (lesson planning, reading comprehension, recognition) to better understand and compare network structure in schools and grade levels.

We assessed the density of the grade level teams to determine the percentage of ties within each of the grade levels. The density of a network can be thought of as a measure of network connectedness or cohesion (Blau, 1977). Density is calculated as the number of connections between actors divided by the number of total possible connections in the network. This means that the greater the proportion of social relationships between school staff members, the more dense the social network. Density was scaled between 0 (indicating no relationships between teachers) to 1 (representing a social network in which all teachers are connected to one another). A dense network is thought to be able to move resources more quickly than a network with fewer ties (Scott, 2000). Density was calculated for each of the elementary grade level teams within schools. Moreover, we calculated the average density per grade level to explore possible variations between grade levels across schools. It is important to note that the sample schools and grade levels were comparable with respect to school and team size allowing for comparison between grade levels as well as across schools.

We measured the rate of interaction between individuals in grade levels and their respective support staff (principals and coaches) by calculating the number of incoming and outgoing ties between grade level teams and support staff, divided by network size. The rate of interaction varied on a scale of 0 (indicating no in or out ties to support staff) to 1 (all grade level team members had frequent reform-related interaction with all support staff members). The higher the rate of interaction, the more grade level members were in contact with support staff around reform-related topics. We measured the level of reciprocity between teachers in grade levels to establish the percentage of reciprocal relationships within each grade level as higher levels of reciprocity have been associated with increased organizational performance and complex knowledge exchange (Kilduff and Tsai, 2003). Reciprocity was calculated using a scale of 0 to 1, with 0 representing no mutual relationship present in the grade level team, and 1 representing a grade level team in which all relationships are reciprocated, controlling for the size of the network.

For each of the individual actors, we calculated their centrality in the social networks by determining the total amount of ties an actor received and sent in each of the networks divided by the size of the network. Centrality can vary on a scale of 0 (the teacher has no in- and out-going relationships and occupies a marginal position in the social network) to 1 (the teacher initiates all the in- and outgoing ties and occupies the central position in the network). Centrality was analyzed as network data to better understand overall the overall structure of the network.

We also conducted a series of Quadratic Assignment Procedure (QAP) correlations in UCINET to determine the similarity between the three reform networks. QAP correlations must be used to run correlational analysis on social networks as relations between individuals are nested and embedded within the same network. When conducting social network research, statistical assumptions of independence, on which Pearson correlations rest, are violated. The QAP correlation procedure follows a specific process. First a Pearson correlation coefficient is calculated for two corresponding 
cells of two rosters that contain network data. Then, it randomly permutes the rows and columns of one of the matrices hundreds of times (each time computing a new correlation coefficient), and compares the proportion of times that these random correlations are larger than or equal to the original observed correlation. A low proportion $(p<.05)$ suggests a strong relationship between the matrices that is unlikely to have occurred by chance (Baker and Hubert, 1981). QAP results for our study indicated that all three network structures were weakly related (lesson planning and reading comprehension $r=.25$; lesson planning and effort recognition $r=.29$; reading comprehension and effort recognition $\mathrm{r}=.21$ ). While the social network questions all examined reform-related interactions among teachers, the weak correlations suggest that each of the three networks measures a different aspect of reform-related interactions. In addition, we conducted more traditional Pearson correlations on the relationships between network measures (density, interaction rate with support staff, reciprocity) and teacher work measures (collective action, efficacy, and satisfaction) to determine the presence of any significant relationships between the study variables.

Teacher work measures data collection. In addition to the social network questions, the 196 participants were asked to respond to three additional measures of the grade level: collective action, grade level efficacy, and satisfaction with collaboration. The action and efficacy instruments were based on previously developed and validated teacher surveys (Bryk, Camburn, and Louis, 1999, Goddard, Hoy and Woolfolk Hoy, 2000) and the satisfaction scale was developed for the study (see Table 3). The measures were aggregated to the grade level as they were intended to assess the collective phenomena.

\section{Insert Table 3 About Here}

Collective Action (CA). The collective action instrument measured the perception of collaborative engagement in tasks around teaching and learning such as the development of common lessons, feedback around instructional practices, review of student work, and focus on teaching and learning using a five-point Likert type agreement scale with the anchors $1=$ strongly disagree and $5=$ strongly agree. The seven-item scale was designed to assess teachers' collaborative practices within the school and was adapted to both the grade level and reading comprehension focus of the reform studied (Bryk, Camburn, and Louis, 1999). For example, teachers were asked in relation to the reform to assess, "Teachers in our grade level collaboratively review student work to improve instructional practices". Results of principal component analysis with varimax rotation provided evidence that the seven items contributed to a single factor solution, explaining $68.4 \%$ of the variance $(\alpha=.89)$ with individual items loadings from .65 to .83 . We then aggregated the teachers' perception of grade level collective action to the grade level producing an average collective action grade level score.

Grade Level Efficacy (GLE). The Grade Level Efficacy instrument measured the collective efficacy of teachers at the grade level around teaching and learning using a five-point Likert type agreement scale with the anchors $1=$ strongly disagree and $5=$ strongly agree. The survey was based on seven items adapted from the original Goddard, Hoy and Woolfolk Hoy (2000) instrument on collective efficacy. Out of the twenty-one items from the original survey we selected seven that focused most directly on teacher competence from the two-factor solution suggested by Goddard et al (2000). We selected this subset of questions as they were most closely connected to the intent of the district reform and could be modified to reflect a grade level focus. A typical item from this revised scale included, "In our grade level, teachers believe that they have what it takes to get children to learn". Principal component analysis with varimax rotation provided evidence that the seven items 
contributed to a single factor solution explaining $59.5 \%$ of the variance $(\alpha=.82)$ with individual items loadings from .74 to .81. Following the process outlined by Goddard et al (2000), we aggregated the efficacy scores from each teacher creating an average collective efficacy score by grade level.

Collective Satisfaction (CS). The satisfaction scale was an original instrument comprised of three items on a five point satisfaction scale ranging from $1=$ very dissatisfied to $5=$ very satisfied.

Respondents were asked to rate the level of satisfaction with grade-level collaboration related to the reform, collaborative information exchange, and support for collaboration. For example, "What is the level of satisfaction within your grade level around collaboration related to the reform effort." Principal component analysis with a varimax rotation indicated a single factor explaining $70.4 \%$ of the variance $(\alpha=.79)$ with individual items loadings from .81 to .88 .

As a final test of the stability of the individual instruments we entered the collective action, grade level efficacy, and collective satisfaction items into a single principal component analysis to establish the stability of each scale. Using varimax rotation, this analysis resulted in an expected three-factor solution, explaining $68.3 \%$ of the variance, indicating that the three scales assessed separate constructs.

Collection of interview data. While the social network data provided quantitative evidence regarding the structure of networks, and the teacher work measures assessed important elements related to teacher collaboration around reform, interview data offered insights into the nature of the networks in each of the schools. We conducted hour-long individual interviews with teachers using a semi-structured interview guide (Patton, 1990; Spradley, 1980) to provide additional information on the knowledge flow around the reading comprehension reform, the implementation of the reform, and collective interaction within the grade levels. Of the five schools, we selected three elementary schools that most closely mirrored the district's demographic average. Within each school we selected a primary grade (second) and an upper grade (fourth) as the target grade levels from which to select interviewees. These grade levels were chosen to enable between school comparisons as these crossschool grade levels use similar curricular literacy content and undergo standardized achievement testing. Moreover, the selected grade-level teams varied in the density of interactions among the grade level team members. Three of the selected grade-level teams could be typified as moderate to highly dense social structures (densities between .60-.80 on a scale of $0-1$ ) and the other three grade levels were characterized by a sparse social network structure (densities between .08-.20).

From grades two and four in the three schools, individual teacher interviewees were selected based on their position in the social network structure as determined by their centrality in the reading comprehension network. Centrality generally refers to how many ties an actor either initiates or receives and therefore is often thought of as an indicator of influence over the system. Per grade level, two teachers were selected that varied the most in the centrality of their network position. Specifically, we divided the centrality scores of the networks into quartiles and then selected teachers from the 1st (least central) and 4th (most central) quartile. This allowed us to select respondents who varied in regard to their centrality in the social network thus securing a variation in perspective based on network position and resulted in twelve interviewees. We have had success in previous studies (Daly and Finnigan, 2009) using this sampling strategy as a way to select respondents.

Analysis of interview data. The interviews of the twelve teachers were audio-recorded and transcribed 
verbatim. Interview data were analyzed using a constant comparative analysis method (Boeije, 2002; Glaser and Strauss, 1967), as well as checking and rechecking emerging themes (Miles and Huberman, 1994). We grouped responses to the prompt and compared the perspectives of teachers at different grade levels. The themes that arose from this preliminary analysis were then reexamined, looking for patterns across grade levels and schools. This process of constant comparison "stimulates thought that leads to both descriptive and explanatory categories" (Lincoln and Guba, 1985, p. 341). In order to ensure the trustworthiness of interpretations, memberchecking procedures were carried out as emerging themes developed and were shared with participants (Miles and Huberman, 1994).

\section{Results}

Analysis of the social networks and interview data provided a detailed and nuanced understanding of how the district reading comprehension reform has been diffused and implemented. Our findings are presented around four major themes from the data: 1 . Principals are the primary conduits through which the reform is initially diffused; 2 . Significant variability exists within grade levels where the reform is primarily enacted; 3 Instrumental and expressive interactions are associated with collective action; and 4. Instrumental and expressive interactions are associated with efficacy and satisfaction.

\section{Principals are the primary conduits through which the reform initially is diffused}

As an original design component of the change effort, the district drew upon the formal hierarchical structure as the main channel of communicating the reform. Central office administrators informed principals who in turn shared the reform focus with the school staff. Centrality scores from the social network analysis reflected this hierarchical flow of information as principals were sought out for information related to the reform more often than other school staff. In-degree centrality scores, meaning the number of ties a principal received, for principals around reading comprehension information were 3.7 versus 1.8 for all other teaching staff. This finding indicates that on average, principals were nominated as sources of reform-related information more than twice as much as other teaching staff. Higher degree centrality is thought to be an indicator of overall influence in a network. Therefore, this finding suggests that individual principals have a strong potential influence on the diffusion of the reform in relation to other school staff. This finding is triangulated with qualitative data in which interviewees report that principals were the ones that primarily delivered information about the reform, while grade level leaders were described by one teacher as, “... doing the 'on the ground' work making the reform happen."

Interview data revealed that while principals received a similar message from the central office, they varied in the way they approached delivering the reform to school staff. Two of the five principals diffused the reform in a way that can be characterized as a technically oriented information sharing approach. These principals focused more on the "nuts and bolts" aspects of the reform elements such as following scripts and completing associated paperwork. A fourth grade teacher offered, We're basically given an agenda by the administration, and we're told everything that we're supposed to have. We're supposed to turn in meeting minutes. So we have to write down everything that we talk about

In contrast, the three other principals were perceived to diffuse the reform through a collective learning-oriented frame. These leaders carefully outlined the broad scope of the reform, aims, and 
potential outcomes for the school. The principals were perceived as providing both information and guidance around the reform while respecting teachers' ability to implement the effort.

It appears that in these five schools leaders initially shaped and continued to influence the diffusion of information related to the reform. However, interviewees did not indicate that principals changed course in their initial approaches. If principals began the process by focusing on the technical elements of the reform they were likely to continue that path. A second grade teacher illustrated this finding,

I remember for a while, we were just like, 'OK, our focus is reading comprehension.' But nothing was said or done about it for a long time. Eventually, it was brought up again at another staff meeting from our Principal. He then repeated the information and tried to explain it a little bit better, but it was still the same stuff.

Principals were described as having differing levels of skills, knowledge, and understanding of the reform that appeared to impact their ability to diffuse information. This variation may have also been exacerbated by a lack of specific direction provided the principals upon the initial introduction of the reform. This result suggests that the sample schools, even though they were a part of the larger reform effort within the same system, began the reform at vastly different points based on the introduction by the principal. These unequal footings may impact the school staff's ability to engage the change and perhaps ultimately affect the consistency and coherence of reform district-wide.

\section{Significant variability exists within grade levels where the reform is primarily enacted}

Aside from the role of the principals in disseminating information regarding the reform, grade levels (GLs) were the main organizational unit in which teachers interacted around the reform's content, meaning, and execution. Therefore, examining the interaction patterns between GL members is an important element in understanding the diffusion and enactment of the reform.

The density of grade level interactions and rates of interaction between grade levels and support staff were found to vary both within and between schools. Charts 1 and 2 provide the across school aggregated density measures of within GL and between GL and support staff interactions. Findings indicate that on average, the proportions of ties of within grade levels in all three networks are significantly higher than the proportion of interactions outside the grade level, (i.e. with support staff). Support staff (meaning principals and coaches) were instructed to support the implementation of the reform by supplying the grade level with reform-related information, materials, and knowledge on reading comprehension. Despite the presence of support staff, teachers tended to interact most frequently within their grade level, while fewer interactions were reported between grade level members and support staff.

\section{Insert Charts 1 and 2 About Here}

Triangulating this finding, interview data suggests that it was during grade-level weekly meetings where teachers would discuss reading comprehension material, assessment data, student work, and classroom strategies. These grade level meetings appeared to be the primary unit where the reform was understood, co-constructed (Datnow et al., 2006), and enacted. Grade level team members attempt to make sense of and implement the reform drawing on their own collective experience. Referring to this co-construction, a fourth grade teacher commented, 
More than anything, I would say the grade level team is the main support for making it [the reform] work. Administration and the leadership team decide our reading comprehension focus and our team is really the best resource because we can dive into the material together and figure out what lesson we think is great, plan the instruction, and tackle it individually from there.

This suggests that the reform goes through several layers of modification prior to reaching the classroom. The reform is first interpreted by the principal, modified at the grade level, and then finally delivered in the classroom. Although the reform was designed to be consistently enacted throughout the district, grade level interactions appear to modify what occurs at the classroom level. This is neither a commendation nor condemnation of the interaction patterns. However, the finding does suggest both the importance of examining the social structures upon which reforms are layered as well as advancing the more technical elements of reform.

While teachers described their grade level as the primary unit for implementing the reform, considerable variability was found between schools and across the thirty grade levels. We examined the density and reciprocity of reform-related networks within the grade level structures as well as the way in which grade level members described their work. Results from these analyses are provided in Table 4.

Insert Table 4 About Here

On average, most interactions between teachers take place around lesson planning. Considerably less reform-related interaction was noted on knowledge seeking regarding the reading comprehension reform as well as effort recognition. For all five schools, there are much more dense connections around lesson planning $(\mathrm{M}=.47, \mathrm{sd}=.29)$ than reading comprehension $(\mathrm{M}=.14, \mathrm{sd}=$ $.19)$ or effort recognition $(\mathrm{M}=.14$, sd $=.19)$. This result indicates that much more interpersonal activity around the reform was concentrated on lesson planning than seeking reading comprehension knowledge, or recognizing efforts of colleagues who engaged the reform. This pattern also held for the levels of reciprocity within the grade levels with significantly more reciprocal relations existing in the lesson planning relation $(\mathrm{M}=.40 \mathrm{sd}=.37)$ than in reading comprehension $(\mathrm{M}=.09 \mathrm{sd}=.23)$ or effort recognition $(\mathrm{M}=.06 \mathrm{sd}=.19)$. In sum, results indicate that the density and reciprocity of within grade-level interaction regarding the reform varied significantly, both across and within the five sample schools (average standard deviation vary between .19 and .37) (see Table 4).

These differences can also be represented graphically. Figures 1 and 2 represent the Reading Comprehension Networks at two of the schools at which teachers were interviewed. We have selected these schools to represent the range of variability in density and structure of school level networks with similar teacher and school level demographics. Figure 1 represents school $\mathrm{E}$ and is characterized by numerous frequent interactions at the school level and densely connected grade levels with few isolates (no frequent interactions with other members in the network, visualized as dots in the upper left corner). Figure 2 displays school $\mathrm{C}$ that consists of fewer school level interactions, more loosely connected grade levels, with more isolates and individuals at the periphery of the network.

Insert Figures 1 and 2 About Here 
Differences in grade level interaction seemed to be related to the way in which grade level members describe their collaborative work in the interviews. In those grade levels where more reform-related interactions were indicated teachers described a focus on a common reading goal with a commitment to building professional practice. A fourth grade teacher from a more connected grade level captured the general finding from these densely connected grade levels,

I think that we just all have a common goal, and the most important thing to us is our students. Our goal is to want to better the education of our students and ourselves as professionals. So during our [grade level] meetings we work together to meet that goal. I think that during our meeting time we know this is an opportunity where we have work that needs to be done and this is a time that we can better our teaching practices.

This stands in contrast to how teachers at less connected grade levels describe their experience. A fourth grade teacher from a grade level with fewer interactions around the reform shared, In my grade level, we're doing so many different programs in fourth grade, you know there are two teachers on shared days, then there's the ten day program, I have GATE [high performing/gifted] class, and there's a high point program, that we cannot work together as a grade level, so our grade level is actually pretty fragmented when it comes to planning [the reform].

These findings imply that grade levels are the primary unit through which the reform is understood and enacted and that the social structures within and between grade levels vary considerably. Some grade levels establish clear goals and a focus on improving instruction while others are described as disjointed and have a more fragmented approach to both planning and implementing the effort. It appears that despite a singular district focus and emphasis on consistency, there may be multiple versions of the reform taking place at different levels of depth throughout the district. Moreover, these versions seem to be related to characteristics of the social networks underlying the teams in which the reform effort is implemented. This underscores the importance of social linkages as a key element in the planning and execution of reforms.

\section{Instrumental and expressive interactions are associated with collective action}

In order to understand to what extent the pattern of instrumental (work/content related) and expressive (affective) relationships were related to grade level teacher work measures, we investigated correlations between social network measures and work measures. This examination rendered a number of statistically significant relationships that are identified in Table 4.

Results indicate that the density of lesson planning interactions was associated with grade level scores on Collective Action (CA) (.49, $\mathrm{p}<.05)$. The CA scale assessed the work of the grade level as teachers collaboratively work to improve instruction and student learning. CA addresses specific professional activities that require collective action, such as: sharing lessons, giving feedback on practice, reviewing student data together, and collectively refining instructional practices. Moreover, the rate of interaction of grade levels with their support staff around lesson planning was also correlated with teachers' collective actions $(.43, \mathrm{p}<.05)$. These findings suggest that the more interactions within grade levels and between grade levels and support staff, the more likely these interactions were to focus on teaching and learning. In support of the relationship between instrumental interactions and teachers' collective actions around instruction and student learning, we found that reciprocity of grade level relationships around reading comprehension was significantly 
correlated with teachers' collective actions $(.37, \mathrm{p}<.05)$. This seems to suggest that the more stable and reciprocal the collaborative relationships at a grade level, the more focused the team was on collectively discussing and refining instructional practice.

These findings are triangulated by interview data collected in both dense and sparse networks. The qualitative data provided a more nuanced understanding of teacher exchanges and the context of their collaboration as well as highlighting the degree of variability that exists between grade levels. In general, teachers in more densely connected reform networks noted three major themes: 1. focus on teaching and learning; 2. goal setting and shared decision making; and 3. learning orientation toward the reform.

Focus on teaching and learning. Teachers within densely connected grade levels reported a number of professional activities in which they engaged to improve teaching and learning. Interviewees from densely connected grade levels reported sharing lessons that were directly connected to the reform effort. They also sought opportunities to observe peers, develop lessons on higher order thinking, collaboratively refine instructional practices, and provide feedback on practice. Aside from improvements to teaching and learning, teachers in these densely connected grade levels indicated more frequent use of data for instruction, co-developed curricular assessments, and a focus on student work.

Qualitative findings from the densely connected grade levels stand in stark contrast to those with fewer interactions. In general, teachers in sparsely connected grade levels reported less focus on reform-related practices. In fact, these grade levels were likely to describe a more individual level approach to the reform. A fourth grade teacher in a sparsely connected grade level captured the general theme,

I feel like I'm working on it [reading comprehension] by myself. I have read the book by myself and I then try to implement the lesson in my class by myself. I don't feel like I'm in a professional community.

Goal setting and shared decision-making. Although all grade levels met formally to discuss pedagogical issues, these meetings seem to be conducted in distinctly different ways and at varying levels of depth. Results suggest that the ability to influence the grade level's goals and plans differed with the amount of interactions that took place within the team. In particular, grade levels that were more densely connected reported to have more input on decision making in regard to their weekly agenda. A common practice in these grade levels was to collectively develop a meeting agenda and provide additional opportunities for input and discussion specifically around the reform.

In contrast, grade levels with less frequent interactions often described themselves as on the receiving end of a rigid agenda set by the administration. A second grade teacher offered, "We receive a detailed agenda from our principal saying what we need to cover and talk about and that is the extent to our input." The lack of goal setting opportunities seemed to permeate interviews from these sparsely connected grade levels across teachers and schools. In a more unambiguous description of the lack of input, another second grade teacher from a different school stated, "Oh, we don't make any decisions. We're told everything."

Learning orientation toward reform. Teachers in densely connected teams also reported the creation and use of their own protocols and formats for planning around reading comprehension. These teams 
would frequently mention the development of common lessons and sharing of rubrics, assessments, and other tools to deepen the work of the reform. A fourth grade teacher captured this theme,

We meet every week and we talk about common lessons. We talk about what works, and what doesn't work. When we focused on inference [a reading reform strategy], we actually decided to go back and re-do it. We didn't like what we got the first time. We discuss among the four of us ideas for the lower level, ideas for the higher level, it didn't matter who was teaching what level, we all just talked.

Somebody will share, 'Hey, this is really working.' You know, when I was teaching another grade level, we were just five different islands doing our own thing.

This collaborative learning orientation toward the reform seemed to be present in those grade levels that had more dense connections. In more sparsely connected grade level teams teachers reported a focus on the more 'technical' aspects of the reform such as completing minutes or checklists. There seemed to be less of a focus on implementing the reform with depth. However, it is not to suggest that teachers wanted to maintain this technical approach, rather they expressed an unrealized desire to focus on more substantive issues connected to the reform. However, they often found themselves responding to a combination of administrative dictates and lack of opportunities for building connections that appeared to inhibit the depth engagement with the reform. A fourth grade teacher noted,

I would appreciate the freedom to make our own agenda, to talk about what we need to talk about, focus on more important things instead of filling out all this paperwork, we could get a lot more done and use our limited time wisely. But it seems like there's so much paperwork, so many other little things we have to do. All the other important stuff never gets talked about.

The interviews of teachers from second and fourth grade in densely and sparsely connected grade levels suggested that the overall engagement, depth, and spread of the reform seems to be associated with the density of connections at the grade level. Although in this sample we lack the statistical power to make conclusive claims, we did find statistically significant correlations between grade level density and student achievement scores in literacy. This trend supports our findings around grade level density as well as providing additional evidence to recent studies connecting collaboration and student achievement (Goddard et al., 2007).

\section{Instrumental and expressive interactions are associated with grade level efficacy and satisfaction}

In addition to teachers' collective actions, quantitative results indicate that the amount and nature of grade level interactions was related to more affectively oriented teacher measures, namely grade level efficacy and collective satisfaction with collaboration. Efficacy was a particularly important factor for reform interactions as it was correlated with all three networks. Correlations indicated that the densities of within grade level interactions around lesson planning and reading comprehension were positively related to grade levels' score on the grade level efficacy scale (GLE) (.38 and .49, p<.05 respectively), which measured collective efficacy around student learning. These correlations suggest that teacher teams with more interaction around lesson planning and reading comprehension are also more likely to perceive their ability to collectively affect student learning. Interactions around both lesson planning and reading comprehension were found to be significantly correlated with a grade level's degree of Collective Satisfaction (CS) (.54, p<.05). CS assessed satisfaction with collaborative work around the reform. This finding suggests that interaction within the grade level is related to teacher satisfaction, meaning the more grade levels interact around the 
reform, the more satisfied the team was with the levels of collaboration. Moreover, the more reciprocal the relationships around lesson planning, the more satisfied grade level teachers were with the level of collaboration within their grade level $(.43, \mathrm{p}<.05)$.

Grade level efficacy and collective satisfaction were also associated with the density of interaction within a grade level around recognition (.44 and $.39, \mathrm{p}<.05$ respectively). This suggests that the more grade level members recognized one another for their efforts related to the reform, the higher the grade level's sense of satisfaction with the collaborative efforts as well as the belief that they can affect student learning. Moreover, satisfaction with collaboration also increased with the presence of more reciprocal relationships in the recognition network $(.45, \mathrm{p}<.05)$.

Overall, the pattern emerging from the quantitative data suggests that teachers in grade levels with more dense interactions around the reform are not only more satisfied with their collaboration, but also feel more competent as a team in increasing student performance than teachers in grade levels with fewer interactions. Our qualitative data triangulates these findings. Teachers in densely connected teams often mentioned the importance of working together in meeting reform goals. These teachers also voiced a shared sense of responsibility between team members and an explicit desire to build and maintain a professional school community.

Trust and respect were often cited by teachers as supportive of their team's functioning and providing a forum for open discussions about classroom practices and strategies. Teachers in more densely connected teams also reported drawing on the technical expertise of one another as well as accessing colleagues for emotional support. A fourth grade teacher illustrated this finding, I think we all respect each other, but we also recognize that we're all different... We'll go to Kim for expertise with technology; we'll go to Greg for leadership questions. And I think the four of us feel comfortable that we'd say, 'Man, I'm having a rotten day.' And then somebody will say, 'Don't feel bad. I had a rotten day too.' And it's like 'Wow. I'm not the only one who had a rotten day.'

The level of trust between members also seemed to provide opportunities for advice seeking on complex issues. Teachers reported it was crucial for individual teachers to be able to adapt to the needs and function of the team over personal issues in order to move the team forward on reading comprehension goals. This stands in contrast with less connected teams in which concerns about a lack of coherence and personal agendas were often mentioned.

Teachers in sparsely connected grade levels also noted themes around a lack of safety and being able to balance grade level politics. Educators in grade levels with fewer interactions indicated they tended to stay to themselves and focus on their individual classrooms. A fourth grade teacher shared,

There have been times when I have not known who the safe person is to go to. So I know I've hid myself in my classroom for weeks at a time because I do not want to get involved in the politics.

Taken on balance, the quantitative correlations and interview data suggest that the density of grade level reform networks is associated with important grade level work measures related to the reform. Grade level teams with dense interactions around the reform were found to engage the reform with more depth. Efficacy and satisfaction, two work measures that refer to more 'affective' processes, appear to support a more flexible and learning-oriented approach to the use of reading comprehension strategies in their classrooms. In contrast, less connected grade levels were found to 
follow a more technical and rigid approach to the reform with ready-made procedures and tools to be implemented. Our data suggests higher levels of collective efficacy and relational trust appear to be important in supporting grade level interactions. In addition, teacher recognition of one another was associated with satisfaction with collaboration and a grade level focus on teaching and learning, as represented by a common perception of collective action. However, despite the importance of these social linkages on the change effort, they were not an explicit design feature of the districtwide reform.

\section{Discussion}

In this paper we examined a district that is implementing a system wide reform around literacy across twenty-four schools. Drawing upon the broader literature of social capital and social network theory we examined three reform-related networks: lesson planning, reading comprehension, and recognition within five schools that were also receiving additional support for reform implementation. Findings suggest that the underlying social networks played a significant role in either supporting or constraining the ability of the grade level to understand and implement the reform. Grade levels with more dense interactions between members reported being able to enact the reform at a greater depth than those more sparsely connected grade levels. Moreover, these interaction patterns were associated with a greater focus on teaching and learning as well as increased collective action, grade level efficacy, and collective satisfaction. This suggests the importance of attending to relational linkages as a complementary strategy to a focus on the technical core of enacting reform efforts. We will present several major themes related to reform efforts that are suggested by our study.

Leadership in reform. The primary mechanism for the reform entering and being diffused through the school occurred through the principals. However, principals engaged with the reform quite differently ranging from a more technical focus to a collective learning orientation. Principals appeared to mediate the understanding the scope and depth of the reform. Grade levels independent of interaction patterns seemed to be influenced by the leader's perception of his/her role in diffusing the reform. Similar to other studies (Burch and Spillane, 2004; Honig, 2006, 2008), leaders modified and brokered reform-related resources such as information and knowledge. This suggests that, in this sample, principals acted upon the formal mandates of the reform in a different way that often defined how the reform was understood and ultimately enacted.

Relational linkages in reform. It is apparent from our data that, although embedded in the same school district and under the similar requirements to reform instructional practices, the sample schools communicated and collaborated in distinctively different patterns of social interaction. Similarly, the grade level teams, upon which the implementation of the reform rests, were significantly different in their social structures related to the reform. However, while the reform was targeted at grade level structures, at no point in the reform design were social linkages explicitly addressed as potential facilitators or inhibitors of change. The design of the reform was focused on the more technical aspects of reading comprehension, which supported the development of individual teachers. This human capital focus, especially in the form of new pedagogical strategies and standards, was important in moving the reform forward. However, the lack of attention from the district to the informal social structures of grade levels, which were ultimately enacting the change, may have inhibited deeper engagement with the reform. 
Efforts at reform are layered onto existing social and professional networks that may in fact constrain these efforts in taking hold (Tsai, 2002). To increase the likelihood of successful and sustainable efforts at reform, educational leaders at the district and school level may benefit from a deep consideration of existing teacher networks prior to and during the implementation phase of a reform. Formally creating opportunities and structures for these networks to flourish and generate appropriate and useful pedagogical knowledge may be an important intrinsic element of the reform itself (Smylie and Evans, 2006). It bears noting that this emphasis on the more relational aspects of the reform suggests an equally important supplemental role to the more technical aspects of school improvement that are currently demanded by many educational policy instruments (Spillane, Reiser and Gomez, 2006). It is the interplay of a focus on relationships and technical elements of reform that may yield the most positive outcomes. The challenge is to determine the right proportions of each, which may well vary by context.

Depth of reform. In addition to the reform being 'passed' from the principal to the teaching staff, the reform appeared primarily diffused through grade level interactions. However, grade levels between schools and within schools had significantly different patterns of interactions, levels of reciprocity, and engagement with the reform. Grade levels varied on the amount of time, content, and focus dedicated to the district-wide reform effort with some grade levels spending more time on administrative features while others focused on improving practice. In our sample, it appeared that those grade levels with more interaction also actively co-constructed elements of the reform in terms of lesson development and instructional practices, perhaps enacting the reform with more depth (Coburn, 2003; Datnow et al., 2006). From a network perspective this suggests that along with the principal's role, the social networks at the grade level may have played a supportive or inhibiting role in the depth of understanding and enactment of the reform.

The importance of dense networks is supported by previous research indicating that interaction patterns in networks in which members interact frequently around work-related issues perceive deeper levels of social and professional exchange (Hansen, 1999; Reagans and McEvily, 2003). When working in collaboration teachers are potentially able to access and make use of the individual and collective resources embedded in their professional network (Rigano and Ritchie, 2003). When teachers design and plan together, best practices may be shared and developed through their discussion, which in turn are taken into classrooms (Little, 2003; Stoll and Louis, 2007). In this study, grade level teams with more interactions appeared to be better able to design and share reform-related pedagogical strategies, assessments, and lessons than less connected teams. Densely connected teams reported engaging the reform with a level of depth that went beyond surface structures and procedures to include a focus on changing classroom practice (Coburn, 2003). Teachers in these more connected grade levels indicated they generated joint productive work and artifacts such as protocol development, lesson study, and common assessments that have been associated with better student outcomes (Chrispeels et al., 2007). That is not to suggest that dense networks are always beneficial for meeting organizational goals. One can imagine a network of grade level 'resistors' that are densely connected, but do not engage in the 'work' of reform. Therefore, dense connections in and of themselves appear a necessary, but not sufficient condition for successful reform. Attending to the content of transactions between grade level teams appears equally important.

Grade level differences in reform. Teachers reported a number of conditions that supported their ability to successfully interact. Educators in more densely connected networks reported ownership and being empowered to set focus of grade level meetings within the parameters of the reform effort. 
Teachers expressed the importance of input around decisions and support for their professional agency in moving reform forward. Growing evidence suggests that, "teacher ownerships of the improvement process is critical to long-term sustainability in school change and student learning" (Chrispeels, 2004, p. 8). In this study, the ability to interact with one another on a more frequent basis around reform was associated with an increased sense of collective efficacy which has been previously associated with student achievement (Bandura, 2003; Goddard et al., 2000; Goddard, Hoy and Hoy, 2004).

Teachers in this study described the importance of trusting relations in their work. This supports other studies that have reported the importance of relational trust as a condition for more productive interactions and overall improved outcomes (Bryk and Schneider, 2002; Daly and Chrispeels, 2008; Tschannen-Moran, 2004). High levels of trust may support the exchange of new strategies, and allow teachers to take instructional risks in improving practice. This ability to take risks creates opportunities for teacher learning that may ultimately impact the depth of engagement in complex reform efforts (Coburn and Russell, 2008). Additional studies have also suggested that informal social bonds based in trust can provide access to specific knowledge pertaining to a strategy and have an effect in adoption and implementation (Frank et al., 2004) thereby enhancing collective processes and outcomes (Nahapiet and Ghoshal, 1998). Interpersonal conflicts and uneasiness with colleagues were found in several of the less connected teams where relationships between teachers appeared strained. This apparent deterioration in relations between grade level members may limit access to reform-related knowledge as well as outcomes. Therefore, improving relationships between members in these less connected grade levels may be of prime importance to the success of the reform.

Using social network data in reform. Although it has been rarely used in improving efforts at change social network data may provide insight into which individuals are in the best structural position (i.e., highly central actors) to move knowledge and practice throughout the system (Daly and Finnigan, 2009). These highly central actors may also serve as points of contact to lesser-connected actors perhaps building the social capital of the entire system and supporting efforts at understanding, implementing and evaluating efforts at reform (Honig, 2006). In addition, using social network data, principals and coaches may be equipped to make more informed decisions about roles and how to best invest their time in providing differentiated support to grade levels. A more coordinated and thoughtful effort at building ties within and between teachers appears important in enhancing an organization's overall capacity for change and increasing the likelihood of success (Daly and Finnigan, 2009; Kogut and Zander, 1996; Moolenaar, Daly, and Sleegers, 2009; Smylie and Evans, 2006). Therefore, as a complementary strategy to the a system-wide reform effort a better understanding of the social relations through which tacit knowledge and practices flow may be an effective strategy in supporting reform.

\section{Delimiters and areas for future research}

There are several limitations to this exploratory case study. Although the case has provided insight into the social structure of a district in need of improvement, it is a case study of reform effort in one district, which limits the generalizability of findings. By focusing the scope of this paper on teacher teams we may have under-represented the connections between the principal and central office staff as well as other school staff, such as reading or special education coordinators at the school site. Moreover, the sample of five schools is too small to infer robust claims from our quantitative data. While the sample size was chosen to conduct a mixed methods study that would provide for the exploration of social networks in reform, we acknowledge the need for large-scale 
empirical studies that can substantiate our findings in larger and more divers samples. Lastly, we only interviewed twelve teachers in three schools and despite randomly selecting individuals from a range of degrees of centrality the interviewees may not be representative of the larger sample. These delimiters of the study also point to additional areas for inquiry and analysis.

First, we are interested in further examining the social networks in Esperanza, including the networks of innovation and trust to examine whether the similar patterns exists. In addition, networks are dynamic (Kilduff and Tsai, 2003) suggesting the importance of studying networks over time. Longitudinal studies may allow us to examine the interactions between network structures, implementation of change strategy, and resulting outcomes over time. Finally, examining patterns of interaction and collaboration between grade levels and between grade levels and support staff may offer additional insights into structural patterns that may increase our understanding of teachers' collaborative work and the role of coaching within school improvements. Although one of the early steps in empirically examining social networks in reform, our study suggests the importance of examining, and accounting for, relational linkages through which reform flows. When reform goes to school it appears supported by a little help from densely connected 'friends'. To that end, our work adds to the growing chorus of scholars that emphasizes the importance of combining both human and social capital approaches in successfully diffusing and implementing efforts at reform. 


\section{References}

Achinstein, B. (2002). "Conflict amid community: The micropolitics of teacher collaboration", Teachers College Record, 104(3), 421-455.

Agullard, K. and Goughnour, D. S. (2006), Central office inquiry: Assessing organization, roles, and actions to support school improvement, WestEd, San Francisco.

Ahuja, G. (2000), "Collaboration networks, structural holes, and innovation: A longitudinal study", Administrative Science Quarterly, 45(3), 425-455.

Andrews, M. and Lewis, D. (2007), "The dance of influence: Professional relationships evolve as teachers and administrators engage in whole school renewal", Leading and Managing. 13 (1), 91-107.

Baker, F. L. and Hubert. (1981), "The analysis of social interaction data", Sociological Methods and Research, 9, 339-361.

Bakkenes, I., De Brabander, C., and Imants, J. (1999), “Teacher isolation and communication network analysis in primary schools", Educational Administration Quarterly, 35, 166-202.

Balkundi, P. and Kilduff, M. (2005), "The ties that lead: A social network approach to leadership", The Leadership Quarterly, 16, 941-961.

Bandura, A. (2003), Self-efficacy: The exercise of control, New York, NY: Freeman.

Blau, P.M. (1977), Inequality and Heterogeneity, The Free Press, New York.

Boeije, H. (2002), "A purposeful approach to the constant comparative method in the analysis of qualitative interviews", Quality and Quantity. 36, 391-409.

Borgatti, S. and Foster, P. (2003), "The network paradigm in organizational research: A review and typology", Journal of Management, 29(6), 991-1013.

Borgatti, S., Everett, M. and Freeman, L. (2002), UCINET for Windows: Software for social network analysis, Analytic Technologies, Harvard MA.

Bourdieu, P. (1986), "The forms of social capital', in J. G. Richardson (Ed.), Handbook of theory and research for the sociology of education, Greenwood, New York, pp. 241- 258.

Brazer, S. D., and Keller, L. R. (2008). A design research approach to investigating educational decisionmaking. InA. E. Kelly, R. A. Lesh and J. Y. Baek (Eds.), Handbook of design research methods in science, technology, engineering, and mathematics learning and teaching (pp. 284-296). Routledge, Taylor, and Francis, New York.

Bryk, A., Camburn, E., and Louis, K.S. (1999), "Professional community in Chicago elementary schools: Facilitating factors and organizational consequences", Educational Administration Quarterly, 35, 751-781.

Bryk, A. and Schneider, B. (2002), Trust in schools: A core resource for school improvement, Russell Sage Foundation, New York.

Burch, P., and Spillane, J. (2004), Leading from the middle: Mid-level district staff and instructional improvement, Cross City Campaign for Urban School Reform, Chicago.

Burt, R. S. (1992), Structural holes: The structure of competition, Harvard University Press, Cambridge, MA.

Carley, K. and Krackhardt, D. (1999), "Cognitive inconsistencies and non-symmetric friendship", Social Networks, 18(1), 1-27.

Carmichael, P., Fox, A., McCormick, R., Procter, R. and Honour, L. (2006), “Teachers' networks in and out of school", Research Papers in Education, 21(2), 217-234.

Chrispeels, J. (2004), Learning to lead together: The promise and challenge of sharing leadership, Sage Publications, Thousand Oaks. 
Chrispeels, J. H., Andrews, C., and Gonzalez, M. (2007), "System Supports for Teacher Learning and School Improvements", in Townsend (Ed.) International Handbook of School Effectiveness and Improvement, Springer Dordrecht, NL, pp. 579-596

Coburn, C. (2003), "Rethinking scale: Moving beyond numbers to deep and lasting change", Educational Researcher, 32(6), 3-12.

Coburn, C. E. and Russell, J. L. (2008), “District Policy and Teachers' Social Networks", Education Evaluation and Policy Analysis, 30(3), 203-235.

Coleman, J. S. (1988), "Social capital in the creation of human capital", American Journal of Sociology, 94, 95-120.

Coleman, J. S. (1990), Foundations of social theory, Harvard University Press, Cambridge MA.

Copland, M. A., and Knapp, M. S. (2006), Connecting leadership with learning: A framework for reflection, planning and action, Association for Supervision and Curriculum Development, Alexandria, VA.

Cross, R. and Parker, A. (2004), The hidden power of social networks: Understanding how work really gets done in organizations, Harvard Business School Press, Cambridge MA.

Cross, R., Baker, W. and Parker, A. (2003), "What creates energy in organizations?”, Sloan Management Review 44(4), 51-57.

Daly, A. J. and Chrispeels, J. (2008), "A Question of Trust: Predictive Conditions for Adaptive and Technical Leadership in Educational Contexts", Leadership and Policy in Schools, 7(1) 30-63.

Daly, A. J. and Finnigan, K. (2009), "Understanding Network Structure to Understand Change Strategy", Journal of Educational Change, DOI 10.1007/s10833-009-9102-5.

Datnow, A. and Castellano, M. (2003), Leadership and success for all, in J. Murphy and A. Datnow (Eds.) Leadership for school reform: Lessons from comprehensive school reform designs, Corwin Press, Thousand Oaks, CA, pp. 187-208.

Datnow, A., Lasky, S., Stringfield, S., and Teddlie, C. (2006), Systemic integration for effective reform in racially and linguistically diverse contexts, Cambridge University Press, Cambridge.

Dika, S. L., and Singh, K. (2002), "Applications of social capital in educational literature: A critical synthesis”, Review of Educational Research, 72, 31-60.

Durrant. J. and Holden, G. (2006), Teachers Leading Change: Doing Research for School Improvement, Paul Chapman Publishing, London.

Earl, L., and Katz, S. (2007), "Leadership in networked learning communities: Defining the terrain", School Leadership and Management, 27(3), 239-258.

Earl, L., Katz, S., Elgie, S., Ben-Jaafar, S., and Foster, L. (2006), How networked learning communities work, Aporia Consulting Ltd., available at http://networkedlearning. ncsl.org.uk/collections/network-research-series/reports/how-networked-learningcommunities-work.pdf.

Elmore, R. F., and Burney, D. (1997), Investing in teacher learning: Staff development and instructional improvement in Community School District \#2, New York City, National Commission on Teaching and America's Future and the Consortium for Policy Research in Education, New York.

Frank, K. A., Zhao, Y., and Borman, K. (2004), "Social capital and the diffusion of innovations within organizations: Application to the implementation of computer technology in schools", Sociology of Education, 77(2), 148-171.

Friedkin, N. and Slater, M. (1994), "School leadership and performance: A social network approach", Sociology of Education, 67, 139-157.

Fullan, M. (2005), Leadership and sustainability: System thinkers in action, Corwin Press, Thousand Oaks. CA.

Giddens, A. (1979), Central Problems in Social Theory, University of California Press, Berkeley, CA.

Glaser, B., and Strauss, A. (1967), The discovery of grounded theory, Aldine De Gruyter, New York. 
Goddard, R. G., Hoy, W. K., and Hoy, A. (2004), "Collective efficacy: Theoretical development, empirical evidence, and future directions", Educational Researcher, 33(3), 3-13.

Goddard, R.D., Hoy, W.K. and Woolfolk Hoy, A., (2000), "Collective teacher efficacy: Its meaning, measure, and impact on student achievement", American Educational Research Journal ,37, pp. 479-508.

Goddard, Y. L., Goddard, R. D., and Tschannen-Moran, M. (2007), “Theoretical and empirical investigation of teacher collaboration for school improvement and student achievement in public elementary schools", Teachers College Record, 109(4), 877-896.

Granovetter, M. (1986), The micro-structure of school desegregation, in J. Prager, D. Longshore and M. Seeman (Eds.), School desegregation research: New directions in situational analysis, Plenum Press, New York.

Granovetter, M. S. (1973), “The strength of weak ties”, American Journal of Sociology, 78, 1360-1380.

Granovetter, M. S. (1982), “The strength of weak ties: A network theory revisited”, in P. V. Marsden and N. Lin (Eds.), Social structure and network analysis, Sage, Beverly Hills, pp. 105-130.

Hallinger, P. (1998), "Educational Change in Southeast Asia. The Challenge of creating learning systems, Journal of Educational Administration, 36, 5, 492-509.

Hansen, M. T. (1999), “The search-transfer problem: The role of weak ties in sharing knowledge across organization subunits", Administrative Science Quarterly, 44(1), 82-111.

Hargreaves, D. H. (2001), "A capital theory of school effectiveness and improvement:, British Educational Research Journal, 27, 4, 487-503.

Hargreaves, D. H. (2003), Education Epidemic. Transforming secondary schools through innovation networks, Demos, London, UK.

Hargreaves, A., and Fink, D. (2006), Sustainable leadership, Jossey-Bass, San Francisco.

Haythornthwaite, C. (2001), "Tie strength and the impact of new media", Proceedings of the $34^{\text {th }}$ Annual Hawaii International Conference on Systems Sciences, Maui, Hawaii.

Henig, J. and Stone, C. (2008), "Rethinking School Reform: The Distractions of Dogma and the Potential for a New Politics of Progressive Pragmatism", American Journal of Education, 114(3), 191-218.

Hightower, A. M., Knapp, M. S., Marsh, J. A. and McLaughlin, M. W. (Eds.). (2002), School districts and instructional renewal, Teachers College Press, New York.

Hite, J., Rew, W. and Nsubuga, Y. (2006), "Building bridges for resource acquisition: Network relationships among headteachers in Ugandan private secondary schools", International Journal of Educational Development, 26(5), 495-512.

Hite, J., Williams, E. and Baugh, S. (2005), "Multiple networks of public school administrators: An analysis of network content and structure", International Journal on Leadership in Education, 8(2), 91-122.

Hollingsworth, A. (2004), "The school as a professional learning community: Perspectives from Tasmanian and English schools on the essentials for creating a community of learning in a school", National College for School Leadership, International perspectives on networked learning, available at http://www.ncsl.org.uk/media-93c-59-the-school-as-a-professional-learningcommunity.pdf.

Honig, M. (2006), "Street-level bureaucracy revisited: Frontline district central-office administrators as boundary spanners in education policy implementation", Educational Evaluation and Policy Analysis, 28(4), 357-383.

Honig, M. (2008), "District central offices as learning organizations: How socio-cultural and organizational learning theories elaborate district-central-office administrators' participation in teaching and learning improvement efforts", American Journal of Education, 114, 627-664. 
Honig, M. (2004), “Crafting coherence: How schools strategically manage multiple, external demands", Educational Researcher, 33(8), 16-30.

Honig, M., and Hatch, T. (2004), "Crafting coherence: How schools strategically manage multiple, external demands", Educational Researcher, 33(8), 16-30.

Hopkins, D. and Reynolds, D. (2001), "The past, present and future of school improvement: towards the third age", British Educational Research Journal, 27, 4, 459-475.

Horvat, E., Weininger, E. and Laureau, A. (2003), "From social ties to social capital: Class differences in the relations between schools and parents network", American Educational Research Journal, 40(2), 319-351.

Hubbard, L., Mehan, H. and Stein, M. (2006), Reform as learning, Routledge, New York.

James, C. R., Dunning, G., Connolly, M. and Elliot, T. (2007), "Collaborative practice: a model of successful working in schools", Journal of Educational Administration, 45(5), 541-555.

Johnston, J., Knight, M., and Miller, L. (2007), "Finding time for teams: Student achievement grows as district support boosts collaboration", Journal of Staff Development, 28(2), 14-18.

Kilduff, M. and Krackhardt, D. (2008), Interpersonal networks in organization : cognition, personality, dynamics, and culture: Structural analysis in the social sciences, Cambridge University Press, Cambridge.

Kilduff, M. and Tsai, W. (2003), Social networks and organizations, Sage Publications, London, UK.

Kogut, B. and Zander, U. (1996), "What firms do? Coordination, identity, and learning", Organization Science, 7(5), 502-518.

Krackhardt, D. (2001), "Network conditions of organizational change", paper presented at the Academy of Management Annual Meeting, Washington DC.

Leithwood, K., Mascall, B., Strauss, T., Sacks, R., Memon, N. and Yashkina, A. (2007), "Distributing leadership to make schools smarter: Taking the ego out of the system", Leadership and Policy in Schools, 6(1), 37-67.

Lima, J. A. (2003), 'Trained for isolation: The impact of departmental cultures on student teachers' views and practices of collaboration", Journal of Education for Teaching, 29(3), 197-218.

Lima, J. A. (2004), Social networks in teaching, in F. Hernandez and I. F. Goodson (Eds.), Social geographies of educational change, Kluwer Academic, The Netherlands, pp. 29-46.

Lima, J. A. (2007), “Teachers' professional development in departmentalized, loosely coupled organizations: Lessons for school improvement from a case study of two curriculum departments", School Effectiveness and School Improvement, 18(3), 273-301.

Lima, J. A. (2009), “Thinking more deeply about networks in education”, Journal of Educational Change, DOI 10.1007/s10833-008-9099-1.

Lin, N. (2001), Social capital: A theory of social structure and action, Cambridge University Press, New York.

Lincoln, Y. and Guba, E. (1985), Naturalistic Inquiry, Sage Publications, Thousand Oaks, CA.

Little, J. W. (2003), "Constructions of Teacher Leadership in Three Periods of Policy and Reform Activism", School Leadership and Management, 23(4), 401-419.

Louis, K. S. and Marks, H. M. (1998), "Does professional community affect the classroom? Teachers' work and student experiences in restructuring schools", American Journal of Education, 106 (4), 532-575.

Love, N. (2008), Using data to improve learning for all: a collaborative inquiry approach, Corwin Press, Thousand Oaks, CA.

Massell, D., and Goertz, M. (1999), "Local strategies for building capacity: The district role in supporting instructional reform", paper presented at the Annual Meeting of the American Educational Research Association, Montreal, Canada. 
McGrath, C. and Krackhardt, D. (2003), "Network conditions for organizational change", Journal of Applied Behavioral Science, 39(3), 324-336.

McLaughlin, M. W. and Talbert, J. (2003), Reforming districts: How districts support school reform, University of Washington, Seattle, WA.

McLaughlin, M. W., and Talbert, J. E. (2006), Building school-based learning communities: Professional strategies to improve student achievement, Teachers College Press, New York.

McLaughlin, M. W. and Talbert, J. W. (1993), Contexts that matter for teaching and learning, Context Center on Secondary School Teaching, Palo Alto, CA.

Miles, M. B. and Huberman, M. A. (1994), Qualitative data analysis (2nd ed.), Sage Publications, Thousand Oaks, CA.

Mohrman, S., Tenkasi, R. and Mohrman, A. (2003), "The role of networks in fundamental organizational change", Journal of Applied Behavioral Science, 39(3), 301-323.

Moolenaar, N. M., Daly, A. J., and Sleegers, P. (2009), "Ties with Potential: Social Network Structure and Innovation in Dutch Elementary Schools", paper presented at the European Association for Research in Learning and Instruction (EARLI), Amsterdam, The Netherlands.

Moolenaar, N. M., Sleegers, P., Karsten, S. and Zijlstra, B.J.H. (2009), "Professional learning communities from a social capital perspective: Studying social networks and trust in elementary schools", paper presented at the Annual Meeting of the American Educational Research Association (AERA), San Diego, CA.

Moore-Johnson, S. (2004), Finders and Keepers: Helping New Teachers Survive and Thrive in Our Schools, Jossey-Bass, New York.

Mullen, C. and Kochan, F. (2000), "Creating a collaborative leadership network: An organic view of change", International Journal of Leadership in Education, 3(3), 183-200.

Nahapiet, J., and Ghoshal, S. (1998), "Social capital, intellectual capital, and the organizational advantage", Academy of Management Review, 23(2), 242-266.

Nelson, R. (1989), "The strength of strong ties: Social networks and intergroup conflict in organizations", Academy of Management Journal, 32(2), 377-401.

Newmann, F., and Wehlage, G. (1995), Successful school restructuring, Madison: Center on Organization and Restructuring of Schools, University of Wisconsin-Madison.

Patton, M. Q. (1990), Qualitative evaluation and research methods (2nd ed.), Sage Publications, Newbury Park, CA.

Penuel, W. R., Frank, K. A., and Krause, A. E. (2007), "A social network approach to examining the effects of distributed leadership in schoolwide reform initiatives", paper presented at the Annual Meeting of the American Educational Research Association, Chicago, IL.

Penuel, W. R., Riel, M. R., Krause, A., and Frank, K. A. (2009), “Analyzing teachers’ professional interactions in a school as social capital: A social network approach", Teachers College Record, 111(1), 124-163.

Portes, A. and Sensenbrenner, J. (1993), "Embeddedness and immigration: Notes on the social determinants of economic action", Am. J. Sociology, 98, 1320- 50

Putnam, R. D. (1993), Making democracy work, Princeton University Press, Princeton, NJ.

Reagans, R., and McEvily, B. (2003), "Network structure and knowledge transfer: The effects of cohesion and range", Administrative Science Quarterly, 48(2), 240-267.

Rigano, D. and Ritchie, S. (2003), "Implementing change within a school science department: Progressive and dissonant voices", Research in Science Education, 33, 299-317.

Rorrer, A., Skrla, L. and Scheurich, J. (2008), "Districts as institutional actors in educational reform", Educational Administration Quarterly,44 (3), 307-357.

Scott, J. (2000), Social Network Analysis (2 ${ }^{\text {nd }}$ Ed.), Sage Publications, London. 
Senge, P M. (2006), The Fifth Discipline: The Art and Practice of the Learning Organization, Broadway Business, New York.

Smylie, M. (1996), "From bureaucratic control to building human capital: The importance of teacher learning", Educational researcher, 25, 9-11.

Smylie, M. A. and Evans, A. E. (2006), Social Capital and the Problem of Implementation, in M. I. Honig (Eds), New Directions in Education Policy: Confronting Complexity, State University of New York Press, Albany, pp. 187-208.

Smylie, M., Wenzel, S., and Fendt, C. (2003), The Chicago Annenberg challenge: Lessons on leadership for school development, in J. Murphy and A. Datnow (Eds.), Leadership lessons from comprehensive school reforms, Sage Publications, Thousand Oaks, pp. 135-158.

Spillane, J. P. (1996), "School districts matter: Local educational authorities and state instructional policy", Educational Policy, 1(1), 63-87.

Spillane, J. P. (2006), Distributed leadership, Jossey-Bass, San Francisco.

Spradley, J. P. (1980), Participant observation, Holt, Rinehart and Winston, New York.

Stevenson, W., Bartunek, J. and Borgatti, S. (2003), "Front and backstage processes of an organizational restructuring effort", Journal of Applied Behavioral Science, 39(3), 243-258.

Stoll, L., and Louis, K. (2007), Professional learning communities, Open University Press, Milton Keynes.

Tenkasi, R. and Chesmore, M. (2003), "Social networks and planned organizational change", Journal of Applied Behavioral Science, 39(3), 281-300.

Togneri,W. and Anderson, S. E. (2003), Beyond islands of excellence: What districts can do to improve instruction and achievement in all schools, The Learning First Alliance and the Association for Supervision and Curriculum Development, Washington, D.C.

Tsai, W. (2002), "Social structure of "coopetition" within a multi-unit organization: Coordination, competition, and intraorganizational knowledge sharing", Organization Science, 13(2), 179-190.

Tsai, W. and Ghoshal, S. (1998), "Social capital and value creation: The role of intrafirm networks", Academy of Management Journal, 41(4), 464-476.

Tschannen-Moran, M. (2004), Trust Matters: Leadership for Successful Schools, Jossey-Bass Publishing, San Francisco.

Uzzi, B. (1997), "Social structure and competition in interfirm networks: The paradox of embeddedness", Administrative Science Quarterly, 42(1), 35-67.

Veugelers, W., and Zijlstra, H. (2002), "What goes on in a network? Some Dutch experiences", International Journal of Leadership in Education, 5(2), 163-174

Wasserman, S. and Faust, K. (1998), Social network analysis: Methods and applications, Cambridge University Press, New York.

Wenger, E. (1998), Communites of Practice. Learning, Meaning, and Identity, Cambridge University Press, Cambridge.

Wood, D. (2007), “Teachers' learning communities: Catalyst for change or a new infrastructure for the status quo?", Teachers College Record, 109(3), 699-739.

Yin, R. K. (2003), Case study research, design and methods, 3rd ed. Sage Publications, Newbury Park. 


\section{Tables}

Table 1: Sample Demographics: School Level

\begin{tabular}{|c|c|c|c|c|c|c|c|}
\hline School & Enroll & $\begin{array}{c}\text { Free/Reduced } \\
\text { Lunch }\end{array}$ & $\begin{array}{c}\text { English } \\
\text { Learners }\end{array}$ & Hispanic & White & $\begin{array}{c}\text { African } \\
\text { American }\end{array}$ & $\overline{\text { API }}$ \\
\hline $\mathrm{A}^{*}$ & 696 & $62.10 \%$ & $53.60 \%$ & $63.40 \%$ & $18.80 \%$ & $5.20 \%$ & 726 \\
\hline B & 777 & $28.10 \%$ & $17.80 \%$ & $27.70 \%$ & $57.80 \%$ & $2.40 \%$ & 875 \\
\hline$C *$ & 779 & $63.20 \%$ & $52.00 \%$ & $73.20 \%$ & $16.90 \%$ & $3.10 \%$ & 709 \\
\hline $\mathrm{D}$ & 729 & $82.90 \%$ & $66.70 \%$ & $88.50 \%$ & $8.20 \%$ & $1.50 \%$ & 692 \\
\hline $\mathrm{E}^{*}$ & 770 & $61.40 \%$ & $52.90 \%$ & $70 \%$ & $20 \%$ & $4.90 \%$ & 762 \\
\hline $\begin{array}{l}\text { Sample } \\
\text { Average }\end{array}$ & 750.2 & $59.54 \%$ & $48.60 \%$ & $64.56 \%$ & $24.34 \%$ & $3.42 \%$ & 752 \\
\hline $\begin{array}{l}\text { District } \\
\text { Average }\end{array}$ & 698 & $61.00 \%$ & $44.80 \%$ & $65.00 \%$ & $25.50 \%$ & $2.90 \%$ & 734 \\
\hline
\end{tabular}

*Interview School; $\mathrm{N}=5$

Table 2: Sample Demographics: School Staff Level

\begin{tabular}{ccccccc}
\hline School & $\begin{array}{c}\# \\
\text { Participants }\end{array}$ & $\begin{array}{c}\% \\
\text { Male }\end{array}$ & $\begin{array}{c}\text { \% } \\
\text { Female }\end{array}$ & $\begin{array}{c}\text { Years at } \\
\text { the school }\end{array}$ & $\begin{array}{c}\text { Years in } \\
\text { current } \\
\text { position }\end{array}$ & $\begin{array}{c}\text { Years as a } \\
\text { educator }\end{array}$ \\
\hline A $^{*}$ & 36 & 14 & 86 & 8.03 & 6.41 & 13.69 \\
B & 42 & 17 & 83 & 8.53 & 6.69 & 16.50 \\
C* & 42 & 7 & 93 & 10.11 & 7.09 & 16.54 \\
D & 35 & 6 & 94 & 7.48 & 5.32 & 12.52 \\
E* $^{*}$ & 41 & 10 & 90 & 9.11 & 7.88 & 18.35 \\
\hline
\end{tabular}

*Interview School; $\mathrm{N}=196$ 
Table 3 Item and factor loadings of the scales used in the study

\section{Collective Actions $(\alpha=.89)$}

1. Teachers in our grade level plan together to meet the needs of diverse learners

2. Teachers in our grade level work collaboratively to implement the instructional focus on reading comprehension

3. Teachers in our grade level collaboratively review student work to improve instructional practices

4. Teachers in our grade level collaborate to provide feedback to colleagues on instructional practice

5. Teachers in our grade level share lessons that lead to meaningful student learning

6. Teachers in our grade level collectively focus on lessons that promote higher order thinking skills

7. Teachers in our grade level have opportunities to observe peers

Grade Level Efficacy $(\alpha=.82)$

1. In our grade level, teachers believe that in spite of family challenges we are able to teach all students to become proficient

2. In our grade level, teachers are skilled on various reading comprehension strategies

3. In our grade level, teachers believe that they have what it takes to get children to learn

4. In our grade level, teachers are well-prepared on reading comprehension instruction to improve student learning

5. In our grade level, teachers truly believe every child can learn

6. In our grade level, teachers are confident they will be able to motivate their students

7. In our grade level, teachers try different methods when a child doesn't learn something the first time

\section{Collective Satisfaction $(\alpha=.79)$}

1. What is the level of satisfaction within your grade level around collaborative information exchange related to the reform effort?

2. What is the level of satisfaction within your grade level around support for collaboration related to the reform effort?

3. What is the level of satisfaction within your grade level around collaboration related to the reform effort?

$\mathrm{N}=196$ 
Table 4: Correlations Between Reform Networks and Teacher Work Measures Reform Networks M SD Action Beliefs Satisfaction

Lesson planning

Density within grade

$.47 \quad .29$

$.49 * \quad .38 *$

$.54^{*}$

Reciprocity within grade

$.40 \quad .37$

$.25 \quad .34$

$.04 \quad .05$

$.43 * \quad .23$

$.43^{*}$

Interaction with Support Staff

$.04 \quad .05$

$.14 \quad .19$

$.25 \quad .49 *$

.28

Density within grade

$.09 \quad .23$

$.37 *$

.24

.14

Interaction with Support Staff

$.01 \quad .03$

.29

$-.24$

\section{Effort recognition}

Density within grade

$.14 \quad .19$

.24

.04

.31

Reciprocity within grade

$.06 \quad .19$

.03

$$
.44^{*}
$$

$.39 *$

$.01 \quad .02$

.29

.23

$.45^{*}$

Interaction with Support Staff

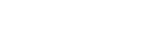

.27

$-.09$

Teacher Work Measures

Collective Action (CA)

\begin{tabular}{ll}
$3.77 \quad .53$ \\
\hline
\end{tabular}

1.00

$.63^{* *}$

.22

$4.17 \quad .40$
3.18

1.00

.30

$3.18 \quad .38$

1.00 collaboration (CS) 


\section{Charts}

\section{Chart 1: Aggregated Within Grade Level Densities Across Sample}

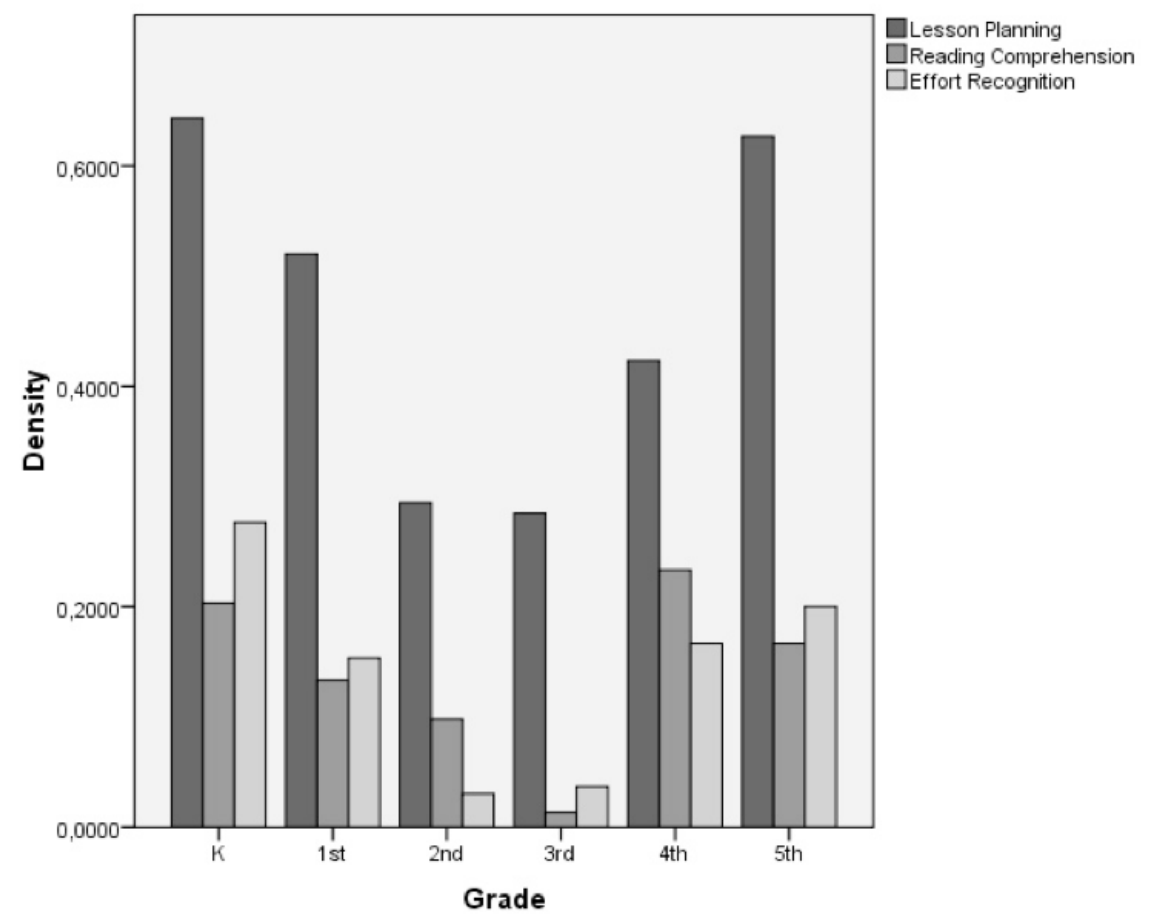

Chart 2: Aggregated Grade Level Rate of Interaction With Support Staff Across Sample

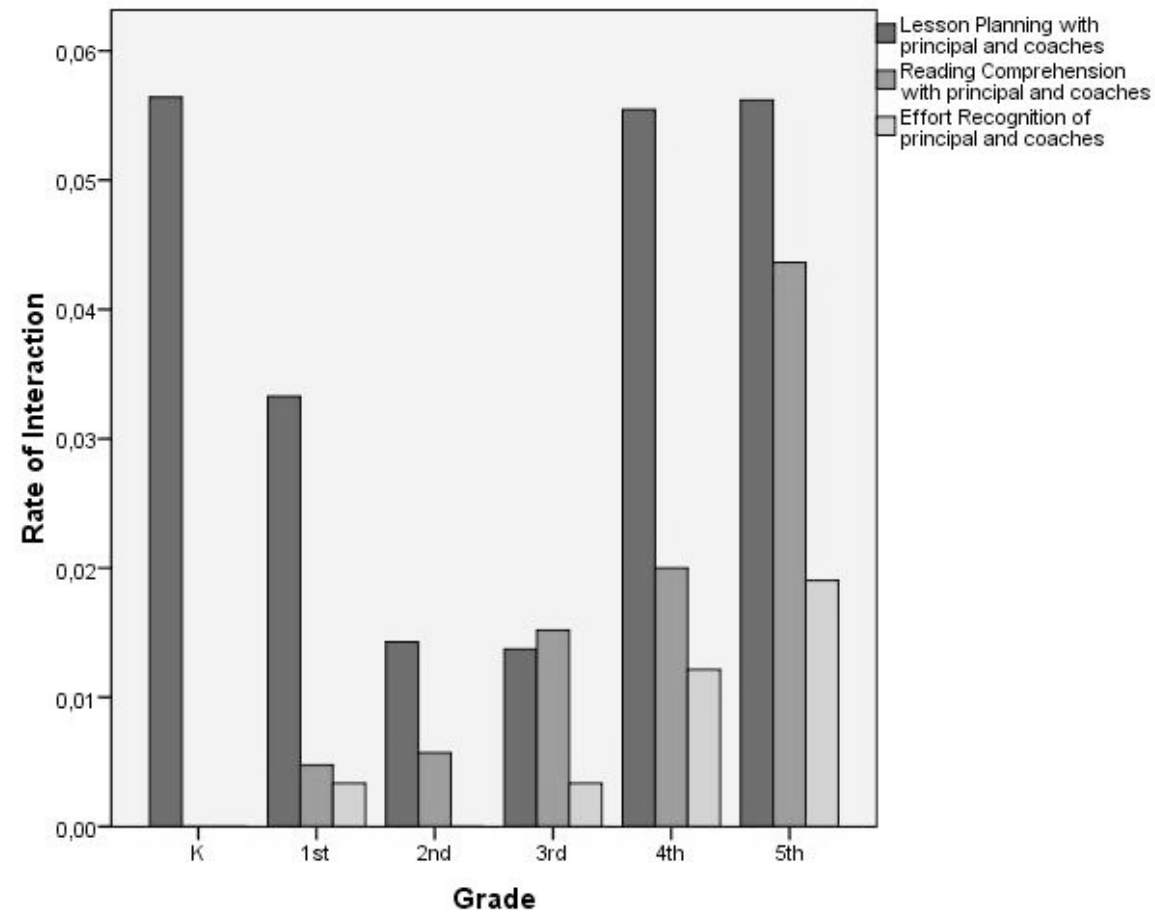




\section{Figures}

Figure 1: Reading Comprehension Network of School E

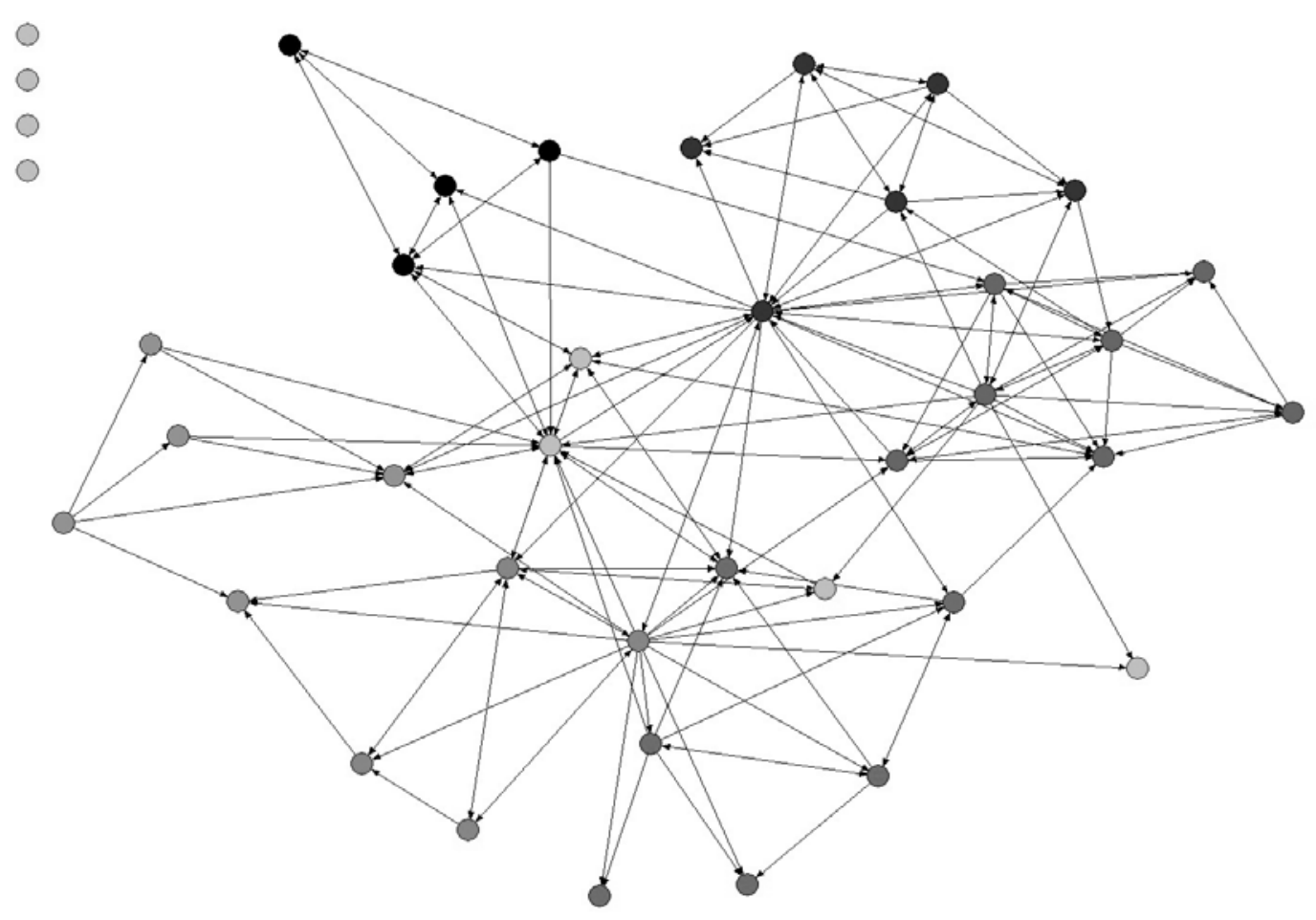

Figure 2: Reading Comprehension Network of School C

0
8
8
8
8
8
8

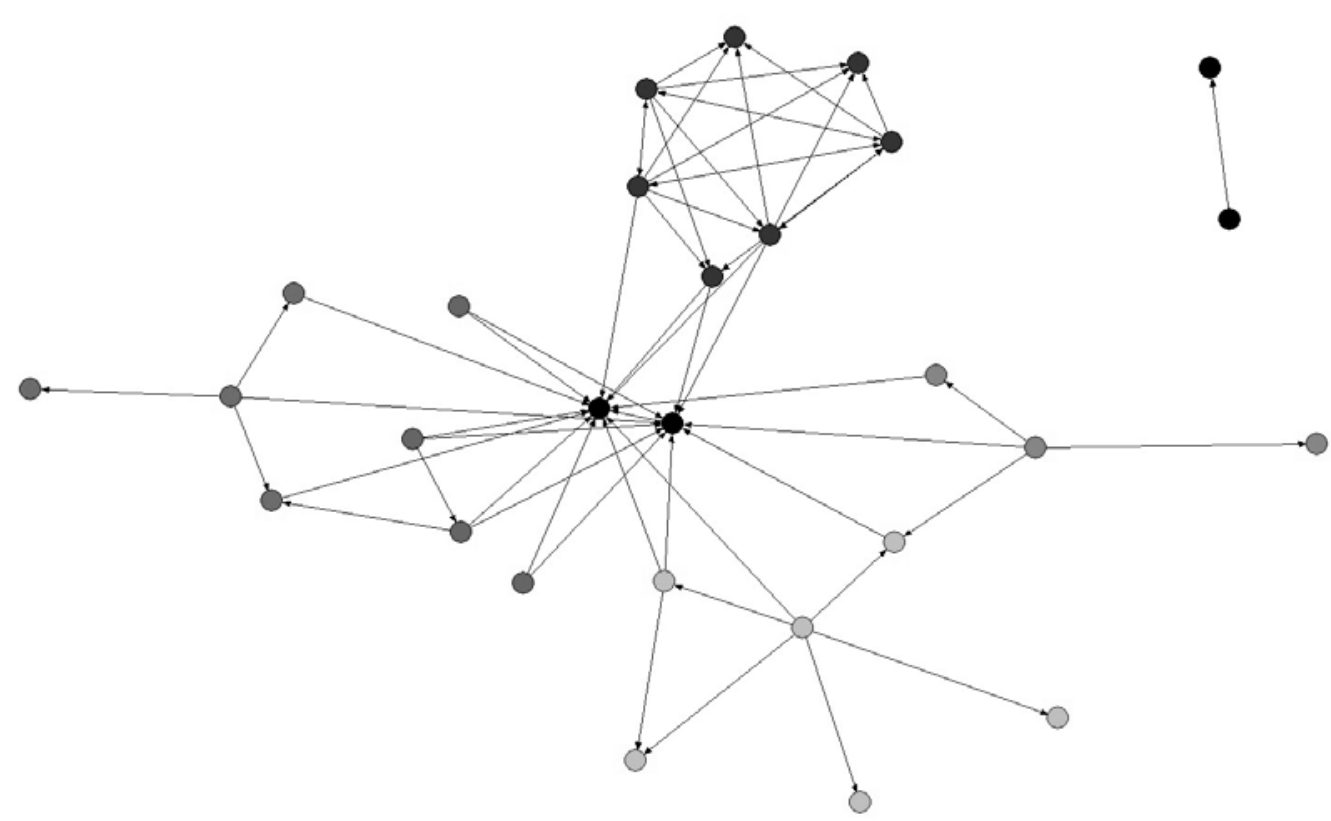

